\title{
Karyotypic characterization of melon accessions
}

\section{Caracterização cariotípica de acessos de meloeiro}

\author{
Rita de Cássia Vital SANTOS-SANCHÊS ${ }^{1}$; Margarete Magalhães SOUZA²; Cláusio Antônio Ferreira de MELO; \\ Gonçalo Santos SILVA ${ }^{4}$ Ronan Corrêa XAVIER ${ }^{5}$; Glauber Henrique de Sousa NUNES ${ }^{6}$; loná Santos ARAÚJO ${ }^{7}$ \\ ${ }^{1}$ Mestre em Genética e Biologia Molecular Universidade Estadual de Santa Cruz (UESC). ritabiologa@yahoo.com.br \\ ${ }^{2}$ Doutora em Produção Vegetal Universidade Estadual de Santa Cruz (UESC). souzamagg@yahoo.com.br \\ ${ }^{3}$ Doutor em Genética e Biologia Molecular Universidade Estadual de Santa Cruz (UESC). clausiomelo@gmail.com \\ ${ }^{4}$ Doutor em Genética e Biologia Molecular Universidade Estadual de Santa Cruz (UESC). goncaloss21@hotmail.com \\ ${ }^{5}$ Doutor em Genética e Melhoramento Universidade Estadual de Santa Cruz (UESC). ronanxc@uesc.br \\ ${ }^{6}$ Doutor em Genética e Melhoramento de Plantas Universidade Federal Rural do Semi-Árido (UFERSA). \\ glauber@ufersa.edu.br \\ ${ }^{7}$ Doutora em Genética e Melhoramento de Plantas Universidade Federal Rural do Semi-Árido (UFERSA). iona@ufersa.edu.br
}

Recebido em: 09-04-2018; Aceito em: 15-10-2018

\begin{abstract}
Cucumis melo (melon) is a species from the Iberian Peninsula and is included in the family Cucurbitaceae. Despite the knowledge about the physical structure of melon chromosomes, little is known about the intraspecific karyotype diversity of the species. To study karyotype diversity in eight melon accessions, the following methods were used: Giemsa 3\% staining; application of $\mathrm{CMA}_{3} / \mathrm{DAPI}$ fluorochromes; and location of $45 \mathrm{~S}$ and $5 \mathrm{~S}$ rDNA sequences by fluorescence in situ hybridization. Conventional staining analysis revealed stability in the chromosome number, with accessions presenting $2 n=24$. There were significant variations in the mean chromosome size between accessions, ranging from $0.98 \mu \mathrm{m}$ to $1.46 \mu \mathrm{m}$ for accessions A26 and A18, respectively. Scott-Knott clustering distributed the accessions into two groups. GC-rich heterochromatic blocks $\left(\mathrm{CMA}_{3}{ }^{+} / \mathrm{DAPI}\right)$ were observed in pericentromeric regions of all chromosomes in the complement. $\mathrm{CMA}_{3}{ }^{+} / \mathrm{DAPI}^{-}$blocks were also located in terminal regions, being specific to satellite regions. Hybridization sites of 45S rDNA probes revealed the presence of a chromosome pair with this locus. In addition, 5S rDNA sites revealed a labeled chromosome pair. No quantitative variation was observed in rDNA sites between the accessions analyzed, indicating these markers as ideal for the verification of karyotypic stability in C. melo.
\end{abstract}

Additional keywords: Cucumis melo, Fluorochromes, FISH.

\section{Resumo}

O Cucumis melo (meloeiro) é uma espécie originária da Península lbérica e está inclusa na família Cucurbitaceae. Apesar do conhecimento a respeito da estrutura física dos cromossomos do meloeiro, pouco se conhece sobre a diversidade cariotípica intraespecífica da espécie. Para estudar a diversidade cariotípica em oito acessos de meloeiro, foram utilizados a coloração de Giemsa a 3\%, aplicação de fluorocromos $\mathrm{CMA}_{3} / \mathrm{DAPI}$ e a localização de sequências de DNAr 45S e 5S, pela hibridação in situ fluorescente. A análise de coloração convencional revelou estabilidade no número cromossômico, com os acessos apresentando $2 n=24$. Foram observadas variações no tamanho cromossômico médio entre os acessos com efeito significativo, com tamanho cromossômico médio variando de 0,98 $\mu \mathrm{ma} 1,46 \mu \mathrm{m}$ para os acessos A26 e A18, respectivamente. O agrupamento de Scott-Knott distribuiu os acessos em dois grupos. Blocos heterocromáticos ricos em GC, $\mathrm{CMA}_{3}{ }^{+} / \mathrm{DAPIforam}$ observados em regiões pericentroméricas de todos os cromossomos do complemento. Blocos $\mathrm{CMA}_{3}{ }^{+} / \mathrm{DAPI}^{-}$ foram localizados também em regiões terminais, sendo específicos de regiões-satélites. Sítios de hibridação de sondas de DNAr 45S revelaram a presença de um par cromossômico com esse lócus. Adicionalmente, sítios para DNAr 5S revelaram um par cromossômico marcado. Não foi observada variação quantitativa nos sítios de DNAr entre os acessos analisados, indicando esses marcadores como ideais para a verificação da estabilidade cariotípica em C. melo.

Palavras-chave adicionais: Cucumis melo, Fluorocromos, FISH.

\section{Introduction}

Family Cucurbitaceae Juss. belongs to the order Cucurbitales, tribe Benincaseae (Schaefer et al., 2009), which occur mainly in tropical and subtropical regions, with few occurrences in temperate regions.
Most species are extremely sensitive to low temperatures, being a limiting factor for their geographical distribution and cultivation area. This family has 118 described genera and approximately 950 species, making it one of the most numerous and heterogeneous families (Judd et al., 2009; Schaefer \& Renner, 2011). 
Fifty-three (53) native genera and approximately three hundred and twenty-five (325) species have been described in the tropical region of America (Nee, 2007; Schaefer \& Renner, 2011). In Brazil, there are approximately 29 genera, comprising 155 species (Gomes-Klein, 2015), where the northeast region alone accounts for 22 genera and 52 species (Gomes-Klein, 2006). Genus Cucumis comprises 32 species (Hoshi et al., 2013), being one of the most important genera in economic terms. It includes many cultivated vegetables such as cucumber, gherkin, and ornamental plants such as gourd and pumpkin. Moreover, melon stands out among the most cultivated vegetables in the world (Muller et al., 2013).

Cytogenetic information has allowed comparison between taxa and the identification of inter- and intraspecific chromosomal variations (Souza et al., 2010; Melo et al., 2011; Guerra, 2013; Melo et al., 2014; Melo et al., 2015; Coelho et al., 2016; Melo et al., 2016; Melo et al., 2017). More detailed information on chromosome structure has been developed in recent studies demonstrating the potential of cytogenetic analysis between taxa for comparisons of genetic and cytogenetic maps among different species and genera (Snowdon et al., 1997). Cytological analyses also contribute to breeding programs, allowing the identification of aneuploids and polyploids, and aiding in the identification of possible chromosomal rearrangements (Sattler et al., 2016).

The main studies on melon genetics report inheritance of growth habit, male sterility, fruit peel color, pulp texture and color, and disease resistance (Lopes et al., 2003). Some studies on Cucumis melo and Cucumis sativus (cucumber) analyze the following topics: chromosomal identification, comparative cytogenetic analysis between taxa of the genus, heterochromatin distribution, satellite DNA mapping, centromeric mapping, 45S and 5S rDNA, genomic analysis, BACs (bacterial artificial chromosomes), and fosmids (Tsuchiya \& Gupta, 1991; Koo et al., 2010; Liu et al., 2010). The location of chromosomal markers in C. melo compared to $C$. sativus has allowed to identify the repositioning of the centromere as the main route in karyotype differentiation and organization between the two species (Liu et al., 2010).

Chromosomes commonly serve as one of the most important molecular aspects in the study of the evolution of species. Thus, most of the crucial mutations that led to species differentiation during evolution occurred at the chromosome level. In addition, chromosome analysis appears to be an invaluable tool for the study of evolution due to its effectiveness in chromosome identification and accurate physical mapping of genes, which can be used in breeding programs (Koo et al., 2010).

The present work performed classical and molecular cytogenetic characterization to locate GCrich heterochromatin and ribosomal DNA sequences in C. melo. In this way, we intend to assess karyotype diversity in commercial varieties of melon for analysis of intraspecific diversity.

\section{Material and methods}

\section{Plant material}

The seeds used were from accessions kept in the Melon Germplasm Bank (C. melo var. momordica) of UFERSA - Federal Rural University of the Semiarid Region. Eight accessions from different Brazilian states were selected (A01, A09, A12, A15, A17, A18, A22, A26), showing cream exocarp and white endocarp. Except for accession A15 (without information), all accessions belonged to variety momordica.

\section{Chromosome preparation}

Seeds were placed to germinate in Petri dish with filter paper moistened at room temperature (RT). Radicles were pretreated with $0.002 \mathrm{M}$ 8-hydroxyquinoline antimitotic solution (Merck $\AA$ ) for 2 hours at RT, washed with distilled water for $5 \mathrm{~min}$ and then fixed in Carnoy's solution (ethanol:glacial acetic acid, 3:1 (v/v), (Merck®), Johansen, 1940) for 3 hours at RT, and stored at $-20{ }^{\circ} \mathrm{C}$ until chromosome preparation. The roots were washed twice in distilled water for $5 \mathrm{~min}$ and incubated in $50 \mu \mathrm{L}$ of enzymatic solution containing $2 \%$ cellulase (Sigma®) and $20 \%$ pectinase (Sigma®) for 1 hour and $20 \mathrm{~min}$ at $37^{\circ} \mathrm{C}$. Then, roots were washed twice with distilled water for $5 \mathrm{~min}$ and macerated in $15 \mu \mathrm{L}$ of $45 \%$ glacial acetic acid (Merck®). Subsequently, the cytological material was spread with the aid of a needle and pressed lightly on filter paper for chromosome spreading. The coverslips were removed after freezing in liquid nitrogen and the slides were air-dried, being subsequently stored in a freezer at $-20^{\circ} \mathrm{C}$ until application of the techniques.

\section{Karyomorphological Analysis}

\section{a) Chromosome morphometry}

For karyomorphological analysis, the slides were stained with Giemsa 3\% (Merck®) for $20 \mathrm{~min}$, dried at RT, and mounted with Neomount (Merck®). Five metaphases were used to measure haploid chromosome length (HCL) (Levan et al., 1964) and mean chromosome length $(x)$ (Huziwara, 1962). Photodocumentation was performed by the DP25 5 megapixel system (DP2-BSW software; Olympus, Tokyo, Japan).

\section{b) Statistical analysis}

Total chromosome length was based on the five best metaphases of each accession studied, according to the best spreading and condensation. The metaphases were measured using Image Tool software, version 3.0. The data were subjected to analysis of variance using SISVAR software, version 5.0 (Ferreira, 2003), and the means of total chromosome length between accessions were compared by the Scott-Knott test $(p<0.05)$. 


\section{$\mathrm{CMA}_{3} / \mathrm{DAPI}$ Banding}

Slides aged for at least three days were subjected to double $\mathrm{CMA}_{3} / \mathrm{DAPI}$ staining, according to the protocol described by Guerra \& Souza (2002), with modification in $\mathrm{CMA}_{3}$ concentration. Then, $10 \mu \mathrm{L}$ of $\mathrm{CMA}_{3}(0.25 \mathrm{mg} / \mathrm{mL})$ was applied to the slide for one hour. The slide was washed in distilled water and airdried. Subsequently, $10 \mu \mathrm{L}$ of $\mathrm{DA}(0.1 \mathrm{mg} / \mathrm{mL})$ was applied for 30 minutes. The slide was washed in distilled water and air-dried. Moreover, $10 \mu \mathrm{L}$ of DAPI $(0.5 \mathrm{mg} / \mathrm{mL})$ was applied for 30 minutes. The slides were washed, dried, and mounted with $15 \mu \mathrm{L}$ glycerol/Mcllvaine $(1: 1 \mathrm{v} / \mathrm{v})+2.5 \mathrm{mM} \mathrm{MgCl} 2$, using $20 \mathrm{x}$ $x 20 \mathrm{~mm}$ coverslips. The slides were aged again for three days prior to microscopic analysis. The images were captured on an Olympus BX41 epifluorescence microscope equipped with a 5 MP Olympus DP25 digital camera and DP2-BSW software. U-UTH filter (330-385 nm excitation / $400 \mathrm{~nm}$ dichroic mirror / > $>420 \mathrm{~nm}$ ) was used to visualize DAPI; and U-MWV filter (450-480 nm excitation / $500 \mathrm{~nm}$ dichroic mirror / > $>515 \mathrm{~nm}$ ) was used to visualize $\mathrm{CMA}_{3}$. Adobe Photoshop $\AA$ CS5 software was used for overlaying images, mounting kariograms, and making photographic plates.

\section{Probe preparation for Fluorescence in situ Hybridi- zation (FISH)}

Primers for partial amplification of the gene 26S from Passiflora, Pe26S-rDNA-F 5'-GGCTGAATCTCAGTGGATCG-3' and Pe26S-rDNA-R 5'-GCTGTCGGTGGACTGCTC-3' (Silva, 2017), were used for the preparation of probes for 45S rDNA sites, which were labeled with biotin-16-dUTP.

Probes for $5 \mathrm{~S}$ rDNA sites were obtained from the product of the polymerase chain reaction (PCR) with the Passiflora-specific primer pair 5'-GTGCGATCATACCAGC(AG)(CT)TAATGCACCGG-3' and 5'-GAGGTGCAACACGAGGACTTCCCAGGAGG-3' (Gottlob-McHugh et al., 1990), labeled with digoxigenin-11-dUTP (Roche Diagnostics $®$ ). Probes were labeled via nick translation (Roche Diagnostics $\AA$ ).

\section{Slide preparation for FISH}

Slide preparation followed the protocol proposed by Schwarzacher \& Heslop-Harrison (2000), modified by Souza et al. (2010). Slides containing the cytological preparations were oven-dried at $37^{\circ} \mathrm{C}$ for a minimum time of $1 \mathrm{~h}$. After application of $50 \mu \mathrm{L}$ RNase $(1 \mu \mathrm{g} / \mathrm{mL})\left(\right.$ Sigma $\left.{ }^{\circledR}\right)$ in $2 \times$ SSC buffer (0.3 M sodium chloride, Sigma $\AA$, 0.03 M sodium citrate, Sigma $\AA$ ), slides were incubated in a humid chamber for $1 \mathrm{~h}$ at $37^{\circ} \mathrm{C}$. Then, slides were immersed twice in $2 \times$ SSC at RT for 5 min each, and $50 \mu \mathrm{L}$ of $10 \mathrm{mM} \mathrm{HCl}$ (Vetec) was applied to the metaphases for $5 \mathrm{~min}$. After removal of the $\mathrm{HCl}, 50 \mu \mathrm{L}$ of pepsin (Sigma®) $[10 \mathrm{mg} / \mathrm{mL}$ pepsin; $10 \mathrm{mM} \mathrm{HCl}(1: 100 \mathrm{v} / \mathrm{v})$ ] was added, and slides were incubated in a humid chamber for $20 \mathrm{~min}$ at $37^{\circ} \mathrm{C}$. The wash steps mentioned below were performed on a shaker platform at $120 \mathrm{rpm}$ (Biomixer, Mos-1). Slides were washed twice in $2 \times$ SSC at RT for $5 \mathrm{~min}$ each, immersed in $4 \%$ paraformaldehyde (Sigma®) at RT for $10 \mathrm{~min}$, and again washed twice in $2 \times$ SSC for 5 min each. Cytological preparations were dehydrated in $70 \%$ ethanol and $100 \%$ ethanol for $5 \mathrm{~min}$ each, for immediate application of FISH techniques.

\section{FISH application}

After drying the slides at RT for $30 \mathrm{~min}$, the hybridization mixture was added to the final volume of $15 \mu \mathrm{L}$, being $50 \%$ formamide (Sigma®), 10\% dextram sulfate (Sigma®), $2 \times$ SSC (Sigma), $0.13 \%$ SDS (sodium dodecyl sulfate; Bioagency), and the probes. Fifty (50) ng of the 26S rDNA probe and fifty (50) ng of the $5 S$ probe were used. The hybridization mixture was heated at $75^{\circ} \mathrm{C}$ for $10 \mathrm{~min}$ in a thermal cycler (Eppendorf Mastercycler), and immediately transferred to ice for $5 \mathrm{~min}$. Cytological preparations containing the hybridization mixture were denatured in a thermocycler containing a slide adapter (Techne, TC-412), at $75^{\circ} \mathrm{C}$ for $10 \mathrm{~min}$, being then incubated overnight at $37^{\circ} \mathrm{C}$ in a humid chamber. After hybridization, slides were immersed in 2x SSC at RT for 5 min for removal of the coverslips. Then, post-hybridization baths were performed in a Dubnoff bath (Quimis, $9226 \mathrm{ML}$ ) at $42^{\circ} \mathrm{C}$, consisting of two immersions in $2 \times \mathrm{SSC}$, for $5 \mathrm{~min}$ each; two immersions in $0.1 \times$ SSC, for 5 min each; and two additional immersions in $2 \times$ SSC, for 5 min each. Slides were immersed in $4 \times \mathrm{SSC} / 0.2 \%$ Tween 20 (Sigma®) at RT for 5 min and treated with $50 \mu \mathrm{L}$ of $5 \%$ BSA (Sigma). Biotin-labeled probes were detected with $0.7 \mu \mathrm{L}$ avidin-FITC (Vector $\left.{ }^{\circledR}\right)$ plus $19.3 \mu \mathrm{L} 5 \%$ BSA per slide. Digoxigenin-labeled probes were detected with $0.7 \mu \mathrm{L}$ anti-digoxigenin-rhodamine (Roche $^{\mathrm{TM}}$ ) plus $19.3 \mu \mathrm{L}$ of $5 \%$ BSA per slide. Slides containing detection antibodies were incubated in a humid chamber for $1 \mathrm{~h}$ at $37^{\circ} \mathrm{C}$. For removal of excess antibody, three baths were performed, for 5 min each, with $4 \times$ SSC $/ 0.2 \%$ Tween 20 at RT. Slides were briefly immersed in $2 \times$ SSC and cytological preparations were simultaneously mounted and counterstained with DAPI/Vectashield $\circledast(\mathrm{H}-1200)$. Then, slides were stored at $8-10^{\circ} \mathrm{C}$ until analysis.

\section{Photodocumentation}

Metaphases were photodocumented using Olympus BX41 epifluorescence microscope equipped with a 5 MP Olympus DP25 digital camera and DP2BSW software. Hybridizations detected with avidinFITC were visualized with U-MWB filter (450-480 nm excitation / $500 \mathrm{~nm}$ dichroic mirror / > $515 \mathrm{~nm}$ ). Hybridizations detected with anti-digoxigenin-rhodamine were visualized with U-MWG filter (510-550 nm excitation / $570 \mathrm{~nm}$ dichroic mirror / > $590 \mathrm{~nm}$ ). Photographic plates, kariograms, and FITC/Rhodamine/DAPI overlays were performed using Photoshop SC5 software. 


\section{Results}

The eight accessions of $C$. melo analyzed in this study are diploids $(2 n=24)$, showing no variation in the chromosome number. Satellite location and identification by conventional staining allowed the observation of two satellite chromosome pairs in all accessions analyzed, except for accession A15, with only one satellite chromosome pair (Figure 1).

Chromosome measurements showed a variation in mean chromosome size from the first to the second chromosome pair, ranging from $1.85 \mu \mathrm{m}$ for the first chromosome pair (accession A18) to $0.78 \mu \mathrm{m}$ for the last chromosome pair (accession A26) (Table 1). Calculations of the standard deviation of mean total length were of low magnitude, indicating that metaphase replicates showed a similar condensation pattern among each other, increasing the reliability of the metric data obtained.

There was a significant difference for mean chromosome size between accessions (Table 2). The Scott-Knott clustering procedure distributed the accessions in two groups of means (Table 3). Accessions A18 and A26 showed the highest and the lowest mean chromosome length, respectively.

Table 1 - Means of the total lengths (TL, in micrometers, $\mu \mathrm{m}$ ) of the chromosomes and standard deviation (SD) in eight accessions of Cucumis melo.

\begin{tabular}{ccccccccc}
\hline \multirow{2}{*}{ Chrom } & A01_RN & A9_CE & A12_PE & A15_AL & A17_BA & A18_PI & A22_MA & A26_SE \\
& TL/SD & TL/SD & TL/SD & TL/SD & TL/SD & TL/SD & TL/SD & TL/SD \\
\hline 1 & $1.59 \pm 0.13$ & $1.74 \pm 0.12$ & $1.41 \pm 0.09$ & $1.36 \pm 0.06$ & $1.68 \pm 0.13$ & $1.85 \pm 0.12$ & $1.72 \pm 0.10$ & $1.22 \pm 0.15$ \\
2 & $1.51 \pm 0.16$ & $1.56 \pm 0.15$ & $1.33 \pm 0.06$ & $1.27 \pm 0.05$ & $1.56 \pm 0.16$ & $1.76 \pm 0.09$ & $1.59 \pm 0.08$ & $1.11 \pm 0.11$ \\
3 & $1.43 \pm 0.15$ & $1.52 \pm 0.13$ & $1.27 \pm 0.04$ & $1.21 \pm 0.03$ & $1.53 \pm 0.18$ & $1.65 \pm 0.03$ & $1.47 \pm 0.02$ & $1.06 \pm 0.07$ \\
4 & $1.38 \pm 0.09$ & $1.42 \pm 0.13$ & $1.22 \pm 0.04$ & $1.18 \pm 0.04$ & $1.43 \pm 0.14$ & $1.59 \pm 0.06$ & $1.41 \pm 0.03$ & $1.03 \pm 0.07$ \\
5 & $1.33 \pm 0.09$ & $1.38 \pm 0.09$ & $1.19 \pm 0.04$ & $1.14 \pm 0.05$ & $1.36 \pm 0.16$ & $1.53 \pm 0.09$ & $1.35 \pm 0.04$ & $1.01 \pm 0.06$ \\
6 & $1.30 \pm 0.09$ & $1.30 \pm 0.10$ & $1.15 \pm 0.04$ & $1.11 \pm 0.05$ & $1.30 \pm 0.16$ & $1.47 \pm 0.07$ & $1.31 \pm 0.03$ & $0.98 \pm 0.06$ \\
7 & $1.27 \pm 0.09$ & $1.31 \pm 0.13$ & $1.11 \pm 0.03$ & $1.09 \pm 0.05$ & $1.29 \pm 0.15$ & $1.44 \pm 0.08$ & $1.26 \pm 0.04$ & $0.96 \pm 0.06$ \\
8 & $1.23 \pm 0.11$ & $1.23 \pm 0.11$ & $1.08 \pm 0.04$ & $1.06 \pm 0.04$ & $1.23 \pm 0.14$ & $1.37 \pm 0.07$ & $1.22 \pm 0.05$ & $0.95 \pm 0.06$ \\
9 & $1.19 \pm 0.13$ & $1.20 \pm 0.12$ & $1.06 \pm 0.04$ & $1.02 \pm 0.02$ & $1.16 \pm 0.09$ & $1.32 \pm 0.07$ & $1.18 \pm 0.05$ & $0.92 \pm 0.05$ \\
10 & $1.16 \pm 0.14$ & $1.14 \pm 0.13$ & $1.05 \pm 0.05$ & $0.99 \pm 0.01$ & $1.12 \pm 0.08$ & $1.25 \pm 0.04$ & $1.13 \pm 0.04$ & $0.89 \pm 0.04$ \\
11 & $1.11 \pm 0.14$ & $1.07 \pm 0.11$ & $1.03 \pm 0.04$ & $0.94 \pm 0.01$ & $1.06 \pm 0.06$ & $1.19 \pm 0.02$ & $1.06 \pm 0.05$ & $0.84 \pm 0.05$ \\
12 & $1.02 \pm 0.12$ & $1.01 \pm 0.12$ & $0.95 \pm 0.03$ & $0.87 \pm 0.05$ & $0.94 \pm 0.08$ & $1.11 \pm 0.05$ & $0.98 \pm 0.06$ & $0.78 \pm 0.04$ \\
\hline
\end{tabular}

\# Origin (States): RN - Rio Grande do Norte; CE - Ceará; PE - Pernambuco; AL - Alagoas; BA - Bahia; PI - Piauí; MA - Maranhão; SE - Sergipe.

Table 2 - Summary of the variance analysis for total chromosome length of the Cucumis melo accessions.

\begin{tabular}{lcc}
\hline Causes of variantion & FD & Average square \\
\hline Accessions & 7 & $0.277320^{*}$ \\
Error & 88 & 0.034107 \\
CV $(\%)$ & 14.81 & - \\
Average & 1.24 & - \\
\hline
\end{tabular}

* Significant by $\mathrm{F}$ test $(\mathrm{p}<0.05)$.

Table 3 - Total chromosome length $(\mu \mathrm{m})$ of Cucumis melo accessions.

\begin{tabular}{cc}
\hline Accessions & Means \\
\hline A01 & $1.29 \mathrm{a}$ \\
A09 & $1.32 \mathrm{a}$ \\
A12 & $1.15 \mathrm{~b}$ \\
A15 & $1.10 \mathrm{~b}$ \\
A17 & $1.31 \mathrm{a}$ \\
A18 & $1.46 \mathrm{a}$ \\
A22 & $1.31 \mathrm{a}$ \\
A26 & $0.98 \mathrm{~b}$ \\
\hline
\end{tabular}

Means followed by the same letters in the column do not differ by Scott-Knott test $(p>0.05)$.
Double staining with fluorochromes revealed heterochromatic $\mathrm{CMA}_{3}{ }^{+} / \mathrm{DAPI}{ }^{-}$blocks in the pericentromeric region of all chromosomes, in all accessions analyzed (Figures 2 and 3). Smaller chromosomes were difficult to visualize (Figure 4). GC-rich heterochromatin restricted to pericentromeric and centromeric regions revealed variations in $\mathrm{CMA}_{3}{ }^{+} / \mathrm{DAPl}{ }^{-}$block size and staining intensity (Figure 4). GC-rich regions were shown in two chromosome pairs in secondary constrictions, revealing the number and location of satellite chromosomes (Figures 3 and 4).

Hybridization of $45 \mathrm{~S}$ rDNA probes revealed four hybridization sites, located on the first and second chromosome pair (Figures 5 and 6). Only one chromosome pair showed hybridization site for 5S rDNA probes (Figures 5 and 6). All accessions had one 5S rDNA locus in the sixth chromosome pair, except accession A09, which revealed this locus in the third chromosome pair (Figure 6). 

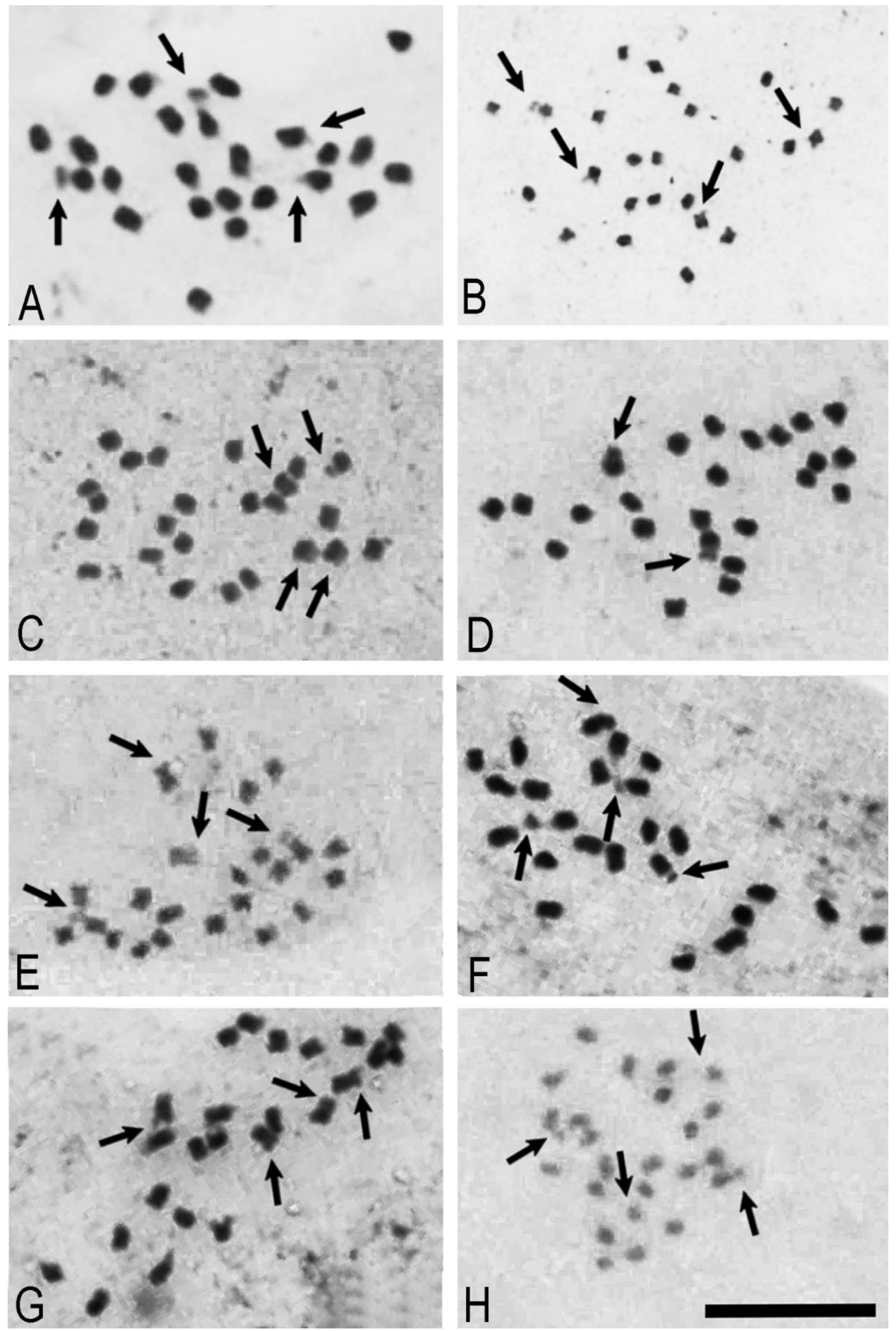

Figure 1 - Mitotic metaphases of commercial varieties of Cucumis melo $(2 n=24)$. A) A12; B) A15; C) A17; D) A18; E) A26; F) A22; G) A01; H) A09. Bar $=10 \mu \mathrm{m}$. The arrows indicate the satellites. 

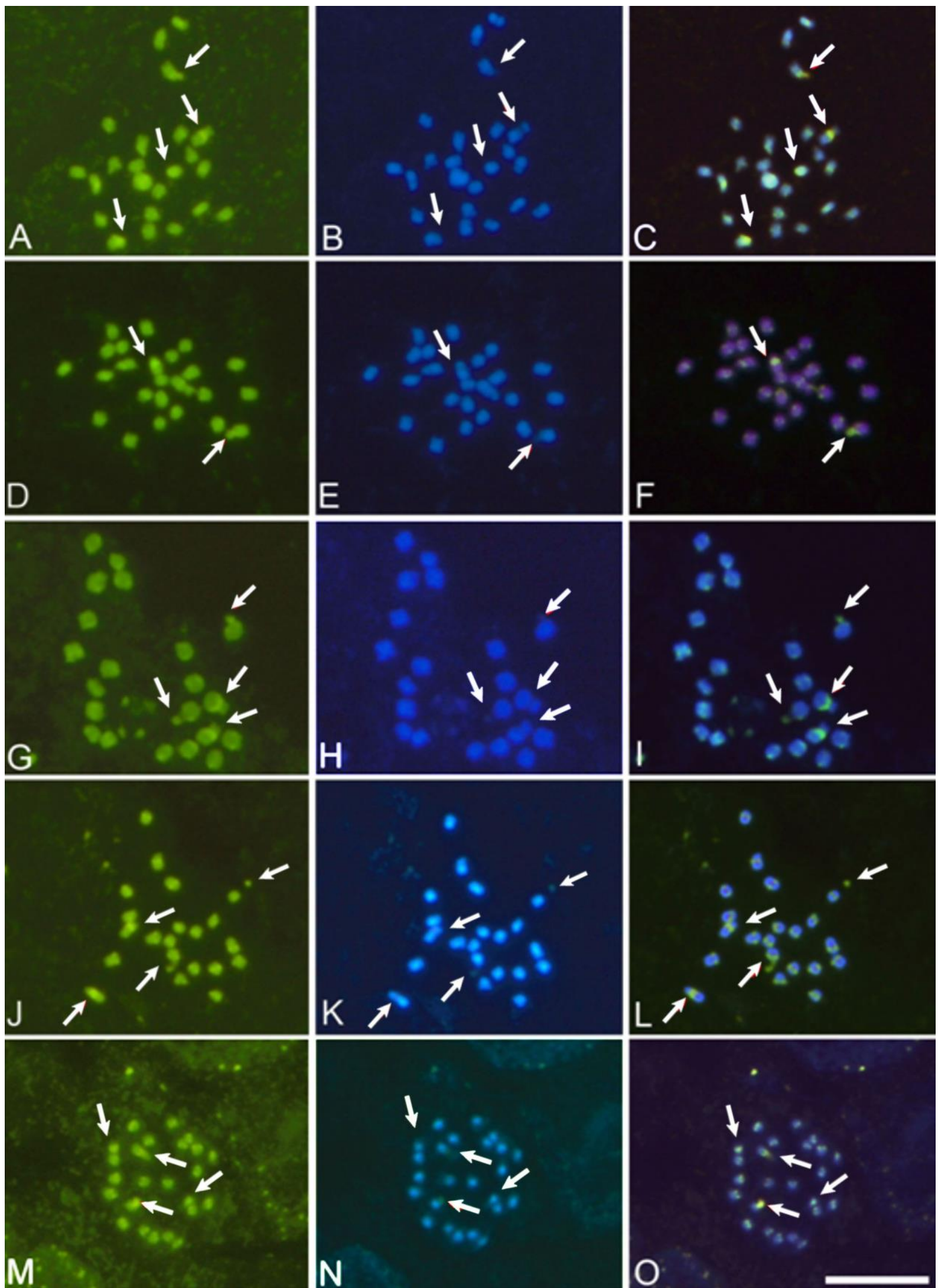

M

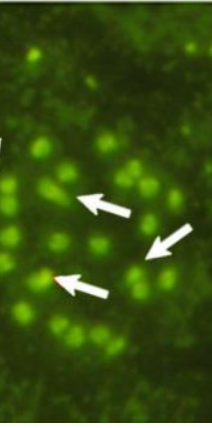

Figure $2-\mathrm{CMA}_{3} / \mathrm{DAPI}$ banding and overlaps in mitotic metaphases of Cucumis melo $(2 n=24)$. A-C) A09; D-F) A12; G-I) A15; J-L) A17; M-O) A18. Bar $=10 \mu \mathrm{m}$. The arrows indicate $\mathrm{CMA}^{3+} / \mathrm{DAPI}$ blocks. 

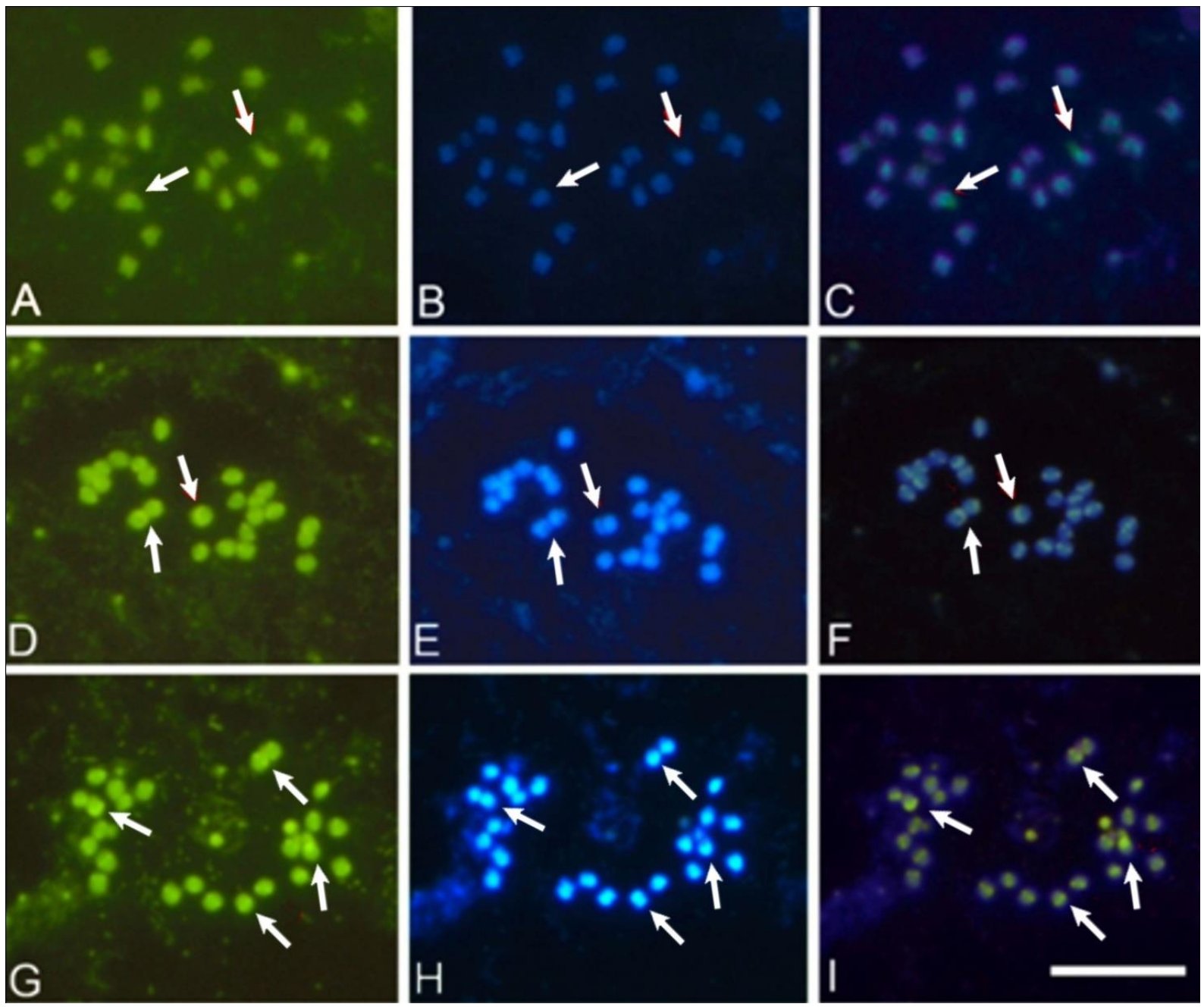

Figure $3-\mathrm{CMA}_{3} / \mathrm{DAPI}$ bandage and overlaps in mitotic metaphases of Cucumis melo $(2 n=24)$. A-C) A22, D-F) A26; G-I) A01. Bar $=10 \mu \mathrm{m}$. The arrows indicate $\mathrm{CMA}_{3}{ }^{+} / \mathrm{DAPI}^{-}$blocks.

\section{Discussion}

Genus Cucumis has been extensively studied as to karyotype characteristics using conventional staining, providing relevant information about interspecific diversity (Trivedi \& Roy, 1970; Singh \& Roy, 1974; Dane \& Tsuchiya, 1976; Ramachandran \& Seshadri, 1986). The chromosome number varies among species, in which diploid ( $2 n=14$ or 24 chromosomes), tetraploid ( $2 n=48$ chromosomes), and hexaploid ( $2 n=$ 72 chromosomes) species stand out (Wang et al., 2017). The basic chromosome number of the genus has been considered as $x=7$ or $x=12$, the latter being the basic chromosome number of the family Cucurbitaceae for most of the diploid species and $C$. melo cultivars already analyzed (Singh \& Roy, 1974; Dane \& Tsuchiya, 1976). The diploid number $(2 n=24)$ was confirmed in C. melo var. momordica, corroborating the data reported in the literature for the species.

The haploid karyotype formula $n=12: 3 m+$ $9 \mathrm{sm}$ was observed for variety momordica, highlighting differences regarding chromosome pairs; however, not characterizing secondary constrictions (Singh \& Roy, 1974).

For momordica, the variation observed in total chromosome length ranged from $0.98 \mu \mathrm{m}$ to $1.46 \mu \mathrm{m}$. However, greater variation was reported $(1.44 \mu \mathrm{m}$ to $2.40 \mu \mathrm{m}$ ) in other varieties of C. melo L. (Singh \& Roy, 1974). There are different reports for the variation in total chromosome length, from 1.20 to $2.50 \mu \mathrm{m}$ (Trivedi \& Roy, 1970), and from $1.1 \mu \mathrm{m}$ to $1.9 \mu \mathrm{m}$ (Ramachandran \& Seshadri, 1986). The variation found in total chromosome length in $C$. melo varieties can be explained by the fact that this species is derived from another Cucumis species, and translocations may have occurred (Singh \& Roy, 1974). In the momordica accessions analyzed, the small length of the chromosomes made it difficult to establish the karyotype formula, being difficult to differentiate the short arm from the long arm. Still, one and two pairs of secondary constrictions were visualized with results different from those previously reported (Singh \& Roy, 1974). 


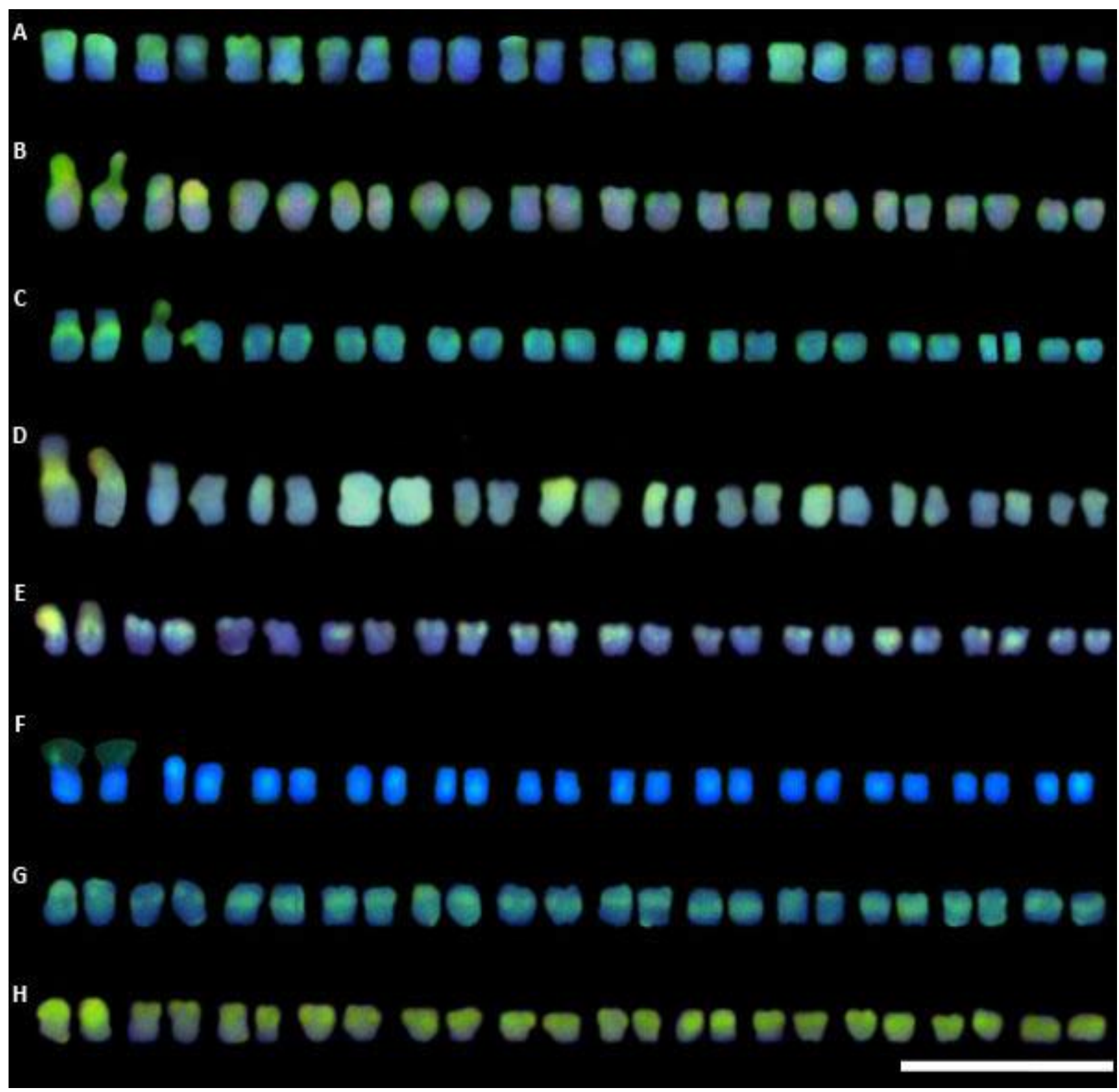

Figure 4 - Cariograms with $\mathrm{CMA}_{3} / \mathrm{DAPI}$ overlays in mitotic metaphases of Cucumis melo $(2 n=24)$. A) A01; B) A09; C) A12; D) A15; E) A17; F) A18; G) A22; H) A26. Bar = $10 \mu \mathrm{m}$.

The comparative evaluation between the accessions studied allowed to verify the occurrence of a karyotype pattern within the species. Intraspecific variations were observed, showing significant differences $(P<0.05)$ regarding total chromosome length. The few variations in the comparative analysis between accessions of $C$. melo var. momordica demonstrated changes in chromatin. However, this analysis was hampered by low karyotype variation, with effects on chromosome identification. Thus, the use of specific chromosome markers appears as a useful tool in C. melo (Liu et al., 2010).

The amount of GC can vary greatly and reflects significant characteristics in the position of plant genomes. The presence of $\mathrm{CMA}_{3}{ }^{+}$blocks in the terminal region of some chromosomes is generally related to the nucleolar organizing regions (NORs) observed in angiosperms (Guerra, 2000). In species of the genus Passiflora, GC-rich regions detected by fluorochrome $\mathrm{CMA}_{3}$ are observed only in $45 \mathrm{~S}$ rDNA/satellite DNA sites (Melo et al., 2001; Viana \& Souza, 2012; Melo et al., 2014; Belo et al., 2015). The distribution of satellite DNA/45S rDNA regarding $\mathrm{CMA}_{3}$ was analyzed in some species of the genus Citrus, and both probes hybridized only with $\mathrm{CMA}_{3}$ and the centromeres (Silva et al., 2010). 

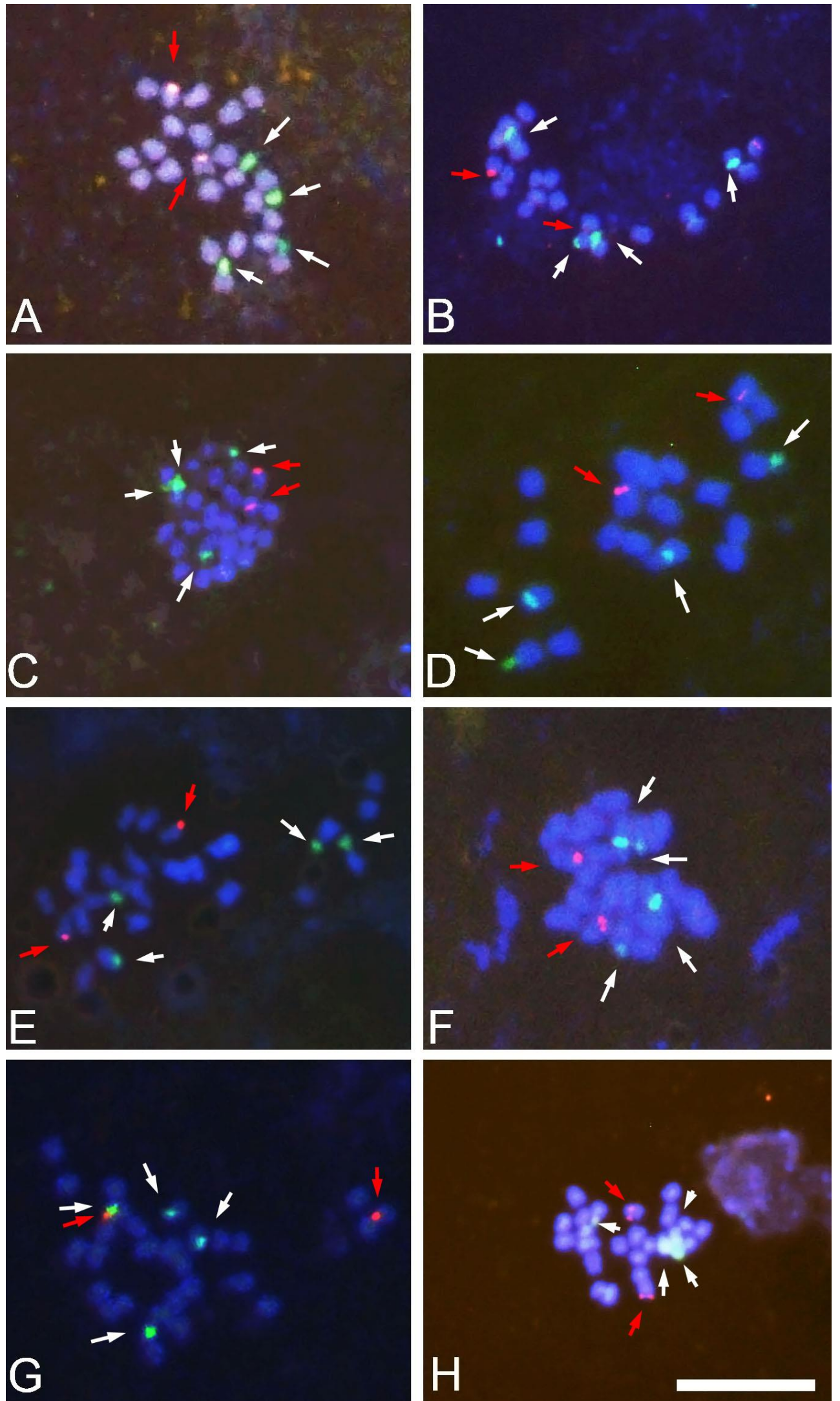

Figure 5 - Fluorescent in situ hybridization with 45S probes (white arrows) and $5 \mathrm{~S}$ (red arrows) in Cucumis melo accessions (2 $n=24)$. A) A01; B) A 09; C) A12; D) A15; E) A17; F) A18; G) A22; H) A26. Bar $=10 \mu \mathrm{m}$. 


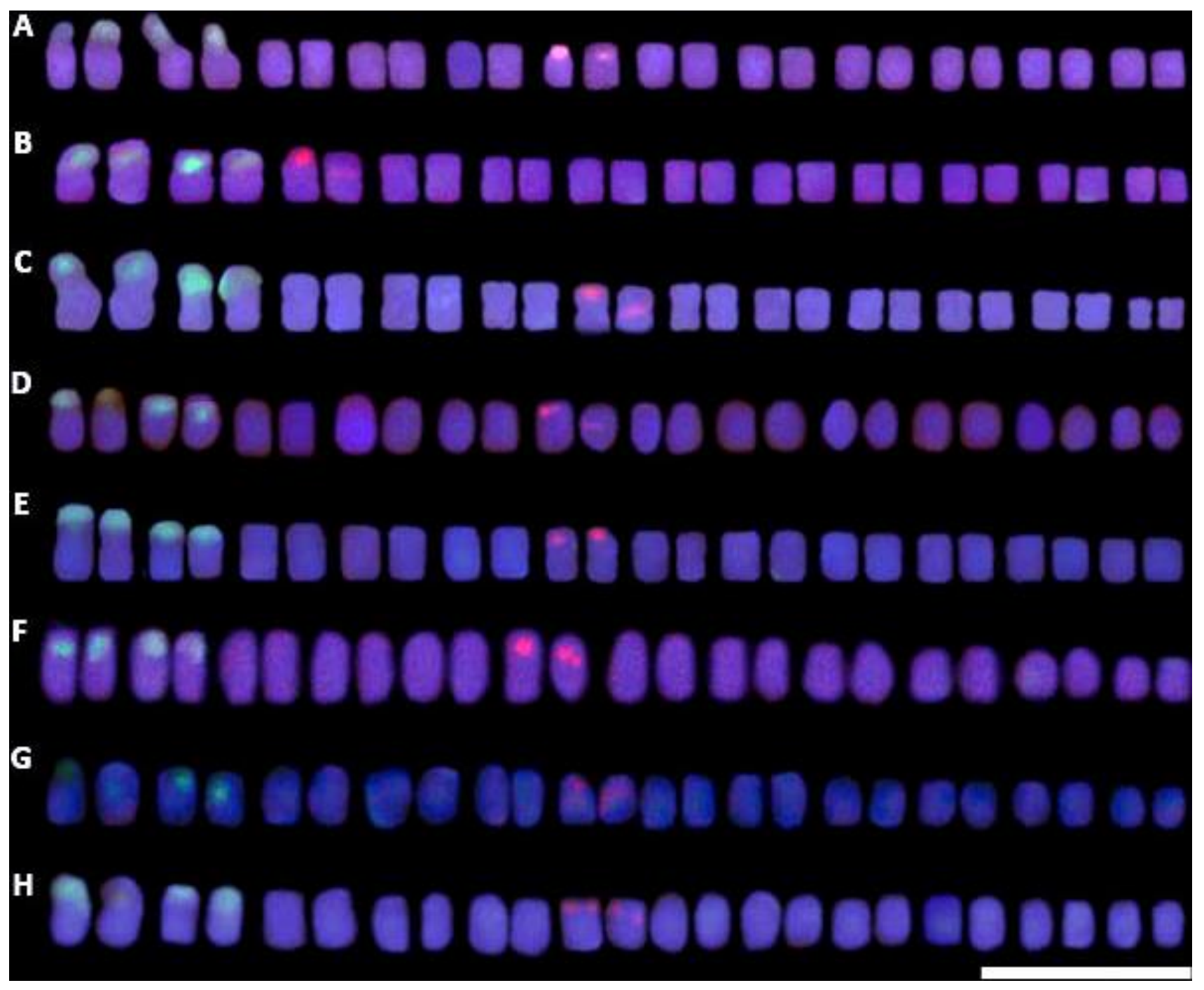

Figure 6 - Cariograms with overlapping 45S (green) and 5S (red) rDNA in mitotic metaphases of Cucumis melo $(2 n=24)$. A) A01; B) A09; C) A12; D) A15; E) A17; F) A18; G) A22; H) A26. Bar $=10 \mu m$

C. melo var. mormordica showed the pattern of $\mathrm{CMA}_{3}{ }^{+} / \mathrm{DAPI}^{-}$bands distributed by centromeric and satellite regions, indicating a high amount of GC-rich heterochromatin. According to Hoshi et al. (2013), only the centromeric and satellite regions are GC-rich. However, in C. melo, CentM DNA is located in pericentromeric regions (Liu et al., 2010). Thus, through $\mathrm{CMA}_{3}{ }^{+}$banding, it was possible to safely identify satellites, which makes them good cytological markers. In this study, it was not possible to identify the location and number of satellites (secondary constriction) through conventional staining, since metaphases were observed, although in an imprecise way.

Hybridization sites of 45S rDNA probes were observed in two chromosome pairs, and 5S rDNA sites in one chromosome pair, corroborating previous studies (Chen et al., 1999; Liu et al., 2010; Hoshi et al., 2013; Li et al., 2016). In C. sativus (same genus as C. melo), research with FISH application using $45 \mathrm{~S}$ and $5 S$ rDNA probes corroborates our study, obtaining one more result from the identification of which chromosomes were marked, since $C$. sativus chromosomes are larger when compared to C. melo (Koo et al., 2002). In other genera, such as Oryza $L$. (Xiong et al., 2006) and Lilium L. (Marasek et al., 2004), FISH application using $45 S$ and 5S rDNA probes obtained the same results of this study.

It is noteworthy that $5 S$ and $45 S$ rDNA sites are sequences conserved on chromosomes and can provide valuable information on karyotype evolution and interspecies relationships. Cytological markers of $C$. sativus have been used in $C$. melo and, through FISH, showed distinct and obvious signals on C. melo chromosomes, derived from genes of the $C$. sativus genome, from repetitive DNA (Liu et al., 2010). These species have relatively small genomes and are similar in size. Among them, there is evidence of conservation of these sequences.

There was no variation with respect to the number and size of hybridization sites of $5 \mathrm{~S}$ and $45 \mathrm{~S}$ rDNA probes, a feature also observed in other studies with C. melo. For example, in a study on the chromo- 
some mapping of $C$. melo compared to $C$. sativus using repetitive sequences, the same number and size of sites was found (Koo et al., 2010). The same result was also found in the characterization of $C$. melo through FISH application, with the same number and size of sites (Chen et al., 1999; Liu et al., 2010). In addition, 5S rDNA has been shown to be more variable than 45S rDNA. Generally, each species has a single $5 S$ rDNA sequence repeated in tandem, often in a single chromosome pair or, less frequent, in two or more pairs (Guerra, 2004).

The diploid accessions of this work presented the same pattern of rDNA distribution when compared to individuals of the same species but from different regions, not differing between each other. Other diploid species analyzed showed three types of rDNA distribution patterns, which provided clear cytogenetic evidence on the divergence between $C$. melo and African diploid wild species of Cucumis. The results not only showed interrelations between species of the genus Cucumis, but also that rDNA patterns can be used as cytological markers for the discrimination of closely related species (Li et al., 2016). The number of rDNA sites is not always associated with the ploidy level. In genus Solanum, for example, tetraploids have the same number of sites as diploids (Melo et al., 2011). Notwithstanding, the relationship between ploidy and the number of $45 S$ and $5 S$ rDNA sites is associated with the diploidization process, seen in polyploids and neopolyploids (Wolfe, 2001).

\section{Conclusions}

Classical and molecular cytogenetic characterization of $C$. melo var. momordica from UFERSA have made it clear that all accessions analyzed have the same constant chromosome number. However, there are variations regarding total chromosome length. The distribution of GC-rich heterochromatin $\left(\mathrm{CMA}_{3}{ }^{+} / \mathrm{DAPI}^{-}\right)$allowed us to verify that these regions are not restricted only to satellites, but to centromeric and pericentromeric regions, showing GC abundance in CentM DNA. With the use of FISH, it was possible to verify chromosomal stability in these markers, indicating that they are ideal for the verification of karyotypic stability in this species.

\section{Acknowledgements}

The authors thank the Santa Cruz State University (UESC) for the infrastructure of the Plant Breeding Laboratory (LAMEP) and the Greenhouse; to CNPq (National Council for Scientific and Technological Development) and to FAPESB (Foundation for Research Support of the State of Bahia) for funding this research; to CAPES (Coordination for the Improvement of Higher Education Personnel) for the scholarships granted to the first, third, and fourth authors; to CNPq for the scholarship granted to the second author; and to Viviane, for the great help in photodocumentation and statistical analysis.

\section{References}

Belo GO, Souza MM, Souza VO, Melo CAF (2015)

Reproductive and cytogenetic characterization in Passiflora sublanceolata. Biologia 70(6):733-743.

Chen RY, Staub JE, Adelberg W, Jiang JM (1999) Physical mapping of $45 \mathrm{~S}$ rRNA genes in Cucumis species by fluorescence in situ hybridization. Canadian Journal of Botany 77(3):389-393.

Coelho MSE, Bortoleti KCA, Araújo FP, Melo NF (2016) Cytogenetic characterization of the Passiflora edulis Sims x Passiflora cincinnata Mast. interspecific hybrid and its parents. Euphytica 201:93-104 (doi: 10.1007/s10681-016-1704-4)

Dane F, Tsuchiya T (1976) Chromosome studies in the genus Cucumis. Euphytica 25(1):367-374.

Ferreira DF (2003) Programa Sisvar. Software 5.0. UFLA, Lavras.

Gomes-Klein VL (2006) Cucurbitaceae. In Checklist das plantas do nordeste brasileiro: angiospermae e gymnospermae. Ministério da Ciência e Tecnologia, Brasília, p.64-66.

Gomes-Klein VL, Lima LFP, Gomes-Costa GA, Medeiros ES (2015) Cucurbitaceae. In Lista de Espécies da Flora do Brasil. Rio de Janeiro. (acessado out 26 2015).

Gottlob-McHugh SG, Levesque M, MacKenzie K, Olson M, Yarosh O, Johnson DA (1990) Organization of the 5S rDNA genes in the soybean Glycine max (L.) Merrill and conservation of the 5S rDNA repeat structure in higher plants. Genome 33(4):486-494.

Guerra D, Pacheco MT, Federizzi LC (2013) Phenotypic, cytogenetic and spike fertility characterization of a population of male-sterile triticale. Scientia Agricola 70(1):39-47.

Guerra M (2004) FISH: Conceitos e aplicações na Citogenética. Sociedade Brasileira de Genética. Ribeirão Preto. 184p.

Guerra M, Souza MJ (2002) Como observar cromossomos: um guia de técnicas em citogenética vegetal, animal e humana. FUNPEC. Ribeirão Preto. 131p.

Guerra M (2000) Patterns of heterochromatin distribution in plant chromosomes. Genetic and Molecular Biology 23(4):1029-1041.

Hoshi Y, Kido M, Yagi K, Tagashira N, Morikawa A, Nagano K (2013) Somatic chromosome differentiation in Cucumis melo L. and C. metuliferus E. Mey. Ex Naudium. Chromosome Botany 8(1):7-12. 
Huziwara Y (1962) Karyotype analysis in some genera of Compositae. VIII. Further studies on the chromosome of Aster. American Journal of Botany 49(2):116119.

Johansen DA (1940) Plant microtechnique, 1 edição, New York, USA: McGraw-Hill Book Co. Ltda, 523p.

Judd WS, Campbell CS, Kellogg EA, Stevens PF, Donoghu MJ (2009) Sistemática Vegetal - Um Enfoque Filogenético. Artmed Editora, 3 edição, 605p.

Koo DH, Hur Y, Jin DC, Bang JW (2002) Karyotype analysis of a Korean Cucumber cultivar (Cucumis sativus L. Cv. Winter Long) using C-banding and bicolor fluorescence in situ hybridization. Molecules and Cells 13(3):413-418.

Koo DH, Nam YW, Choi D, Bang JW, Jong H, Hur Y (2010) Molecular cytogenetic mapping of Cucumis sativus and C. melo using highly repetitive DNA sequences. Chromosome Research 18(3):325-336.

Levan A, Fredga K, Sandberg AA (1964) Nomenclature for centromeric position on chromosomes. Hereditas 52:1-20.

Li KP, Wu YX, Zhao H, Wang Y, Lu XM (2016) Cytogenetics relationships among Citrullus species in comparasion with some genera of the tribo Benincaseae (Cucurbitaceae) as inferred from rDNA distribuition paterns BMC. Evolutionary Biology 16, 85p.

Liu C, Liu J, Li H, Zhang Z, Han Y, Huang S, Jin W (2010) Karyotyping in Melon (Cucumis melo L.) by Cross-Species Formid Fluorescence in situ Hybridization. Cytogenetic and Genome Research 129(1-3):241249.

Lopes JF, Carvalho SIC, Pessoa HBBV (2003) Recursos Genéticos de melão e pepino na Embrapa Hortaliças. In: Queiroz MA, Goedert CO, Ramos SRR. (eds). Recursos genéticos e melhoramento de plantas para o Nordeste Brasileiro Petrolina: EMBRAPACPATSA/Brasília: EMBRAPA-CENARGEN, 8p.

Marasek A, Hasterok R, Wiejacha K, Orlikowska $T$ (2004) Determination by GISH and FISH of hybrid status in Lilium. Hereditas 140(1):1-7.

Melo CAF, Souza MM, Silva GS (2017) Karyotype analysis by FISH and GISH techniques on artificial backcrossed interspecific hybrids involving Passiflora sublanceolata (Killip) MacDougal (Passifloraceae). Euphytica 213:161.

Melo CAF, Souza MM, Viana AP, Santos EA, Souza VO, Corrêa RX (2016) Morphological characterization and genetic parameter estimation in backcrossed progenies of Passiflora L. for ornamental use. Science Horticulture 212:91-103.
Melo CAF, Silva GS, Souza MM (2015) Establishment of genomic in situhybridization (GISH) technique for analysis in interspecific hybrids of Passiflora. Genetics and Molecular Research 14(1):2176-2188.

Melo CAF, Souza MM, Abreu PP, Viana AJC (2014) Karyomorphology and GC-rich heterochromatin pattern in Passiflora (Passifloraceae) wild species from Decaloba and Passiflora subgenera. Flora 209(11):620-631.

Melo CAF, Martins MIG, Oliveira MBM, Benko-Iseppon AM, Carvalho R (2011) Karyotype analysis for diploid and polyploid species of the Solanum L. Plant Systematics and Evolution 293(1-4):227-235.

Melo NF, Cervi AC, Guerra M (2001) Karyology and cytotaxonomy of the genus Passiflora L. (Passifloraceae). Plant Systematics and Evolution 226(1-2):69-84.

Nee M (2007) Flora da Reserva Ducke, Amazonas, Brasil: Cucurbitaceae. Rodriguesia 58(3):703-707.

Muller NG, Fasolo D, Pinto FP, Bertê R, Muller FC (2013) Phytochemical potentialities of melon (Cucumis melo L.) in the northwest region of Rio Grande do Sul Brazil. Revista Brasileira de Plantas Medicinais 15(2):194-198.

Ramachandran C, Seshadri VS (1986) Cytological analysis of the genome cucumber (Cucumis sativus $\mathrm{L}$.) and muskmelon (Cucumis melon L.). Ziel der Pflanzenzuchtung 96:25-38.

Sattler MC, Carvalho RC, Clarindo WR (2016) The polyploid and its key role in plant breeding. Planta 243(2):281-296.

Schaefer H, Renner SS (2011) Phylogenetic relationships in the order Cucurbitales and a new classification of the gourd family (Cucurbitales). Taxon 60(1):122138.

Schaefer H, Heibl C, Renner SS (2009) Gourds afloat: A dated phylogeny reveals an Asian origin of the gourd family (Cucurbitaceae) and numerous oversea dispersal events. Proceedings of Royal Society B 276,843851 (doi:10.1098/rspb.2008.1447)

Schwarzacher T, Haslop-Harrison P (2000) Practical in situ Hybridization. Springer-Verlag Inc. New York. 2003p.

Singh AK, Roy RP (1974) Karyological studies in Cucumis L. Caryologia 27(2):153-160.

Silva GS (2017) Análises genômicas (GISH) e citogenômicas comparativas em espécies do gênero Passiflora L.. Uesc (Tese de doutorado em Genética e Biologia Molecular). 
Silva AEB, Marques A, Santos KGB, Guerra M (2010) The evolution of CMA bands in Citrus and related genera. Chromosome Research 18(4):503-514.

Snowdon RJ, Kohler W, Friedt W, Kohler A (1997) Genomic in situ hybridization in Brassica amphidiploids and interspecific hybrids. Theoretical and Applied Genetics 95(8):1320-1324.

Souza MM, Urdampilleta JD, Forni-Martins ER (2010) Improvements in cytological preparations for fluorescent in situ hybridization in Passiflora. Genetics and Molecular Research 9(4):2148-2155.

Trivedi RN, Roy RP (1970) Karyological studies in Cucumis and Citrullus. Caryologia 35(4):561-569.

Tsuchiya T, Gupta PK (1991) Chromosome Engineering in Plants: Genetics, Breending, Evolution Parte B. Editora Elsevier. 201-214p.
Viana AJC, Souza MM (2012) Comparative cytogenetics between species Passiflora edulis and Passiflora cacaoensis. Plant Biology 14(5):820-827.

Wolfe KH (2001) Yesterday's polyploids and the mistery of diploidization. Nature Reviews Genetics 2(5):333-341.

Wang Y, Zhao Q, Qin X, Yang S, Li Z, Li J, Lou Q (2017) Identification of all homoeologous chromosomes of newly synthetic allotetraploid Cucumis $\mathrm{x}$ hytivus and its wild parent reveals stable subgenome structure. Chromosoma 126(6):713-728.

Xiong ZY, Tan GA, He GY, He GC (2006) Cytogenetic comparisons between $A$ and $G$ genomes in Oryza using genomic in situ hybridization. Cell Research 16:260-266. 